\title{
Prezados/as leitores/as!
}

A Revista Acadêmica Observatório de Inovação do Turismo/RAOIT é uma iniciativa do Núcleo de Pesquisa em Turismo da Unigranrio/NPTU, sob a coordenação da editora-chefe Deborah Moraes Zouain.

Classificada, segundo os critérios Qualis/CAPES, como 'B2', desde 2019 o periódico passou a ser editado com periodicidade quadrimestral, com seus números publicados em: abril, agosto e dezembro.

A missão da RAOIT é estimular a produção e disseminação de conhecimento sobre turismo que possam contribuir para atividades acadêmicas e ações em organizações públicas e privadas.

Aproveitem a nova edição especial "Inovação e Empreendedorismo em Turismo: Interação entre os diferentes atores".

Boa leitura!

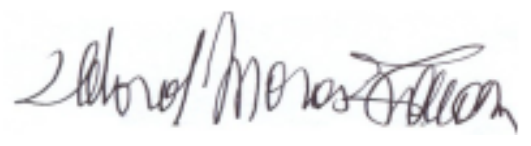

Deborah Moraes Zouain

Diretora e editora-chefe 